\title{
MEDICAL HISTORY IN GERMAN MEDICAL EDUCATION
}

BEFORE discussing the present position of medical history in the German medical curriculum I should like to make some historical remarks. The paper begins therefore with the part played by the history of medicine in Germany during the nineteenth century up to the first world war. Thereafter it will deal with the time between Sudhoff's foundation of the Institute of History of Medicine at the University of Leipzig and the second world war. The main topic will be the period after 1945 when nearly every German medical school established a chair and an institute or department of history of medicine. A short survey of the research that is done in these institutes will follow, and finally we shall glance at the teaching programme of the German medico-historical institutes.

In the beginning of the nineteenth century German medical schools already offered lectures and courses in the history of medicine, like many medical schools in other European countries. But the aim of the instruction was not the same as today. Today a course in the history of medicine is intended to demonstrate to students that medicine is not an isolated phenomenon, but depends on cultural, religious, economic and social factors, and that the actions and thought of the modern physician have been shaped by the theories, doctrines, findings and errors of countless generations of physicians before them. In the first decades of the last century the medical student had to study classical medical authors in order to learn from them how to practise as a good doctor. Kühn's Greek-Latin edition of Galen, published in twenty-two volumes at Leipzig from 1821 to 1833 , applied to the physician, not to the philologist.

This pragmatic conception of the history of medicine was given up about the middle of the century. The leading medical men realized that progress in medicine could not be achieved by persisting in traditional theories or the study of historical texts, but from the scientific approach to disease. The systematic application of physical and chemical methods to the phenomena of life characterized German medical research from the time of Theodor Schwann, Carl Ludwig, and Hermann Helmholtz. There remained no place for the history of medicine: medico-historical lectures disappeared from the curriculum or found no audience.

Although the history of medicine did not enjoy great standing as an academic discipline, the University of Berlin had a chair in medical history. Until 1850 it was occupied by Karl Hecker, the founder of historical epidemiology, and later by August Hirsch, known as the author of the Handbook of Geographical and Historical Pathology. The immense development of the science of general history and the formation of a critical method for historical research from the middle of the nineteenth century encouraged studies in the history of medicine, and particularly original research work in archives and libraries. After the death of August Hirsch, Bismarck passed the chair of history of medicine to his personal physician Ernst Schweninger, who had no knowledge of the subject and never gave a lecture on the history of medicine. Julius Pagel, who was well known in this field, received only the title of professor. This shows how little attention was being paid to the history of medicine by local governments-and medical faculties too.

In 1904 the University of Leipzig received a bequest of 500,000 Marks for the 


\section{News, Notes and Queries}

promotion of the history of medicine from Mrs. Puschmann, the wife of Theodor Puschmann, who had begun his academic career in medical history as Privatdozent at the University of Leipzig, but later taught at the University of Vienna. Leipzig University decided to create a chair in the history of medicine, and Karl Sudhoff was appointed professor. The history of medicine was thus given its first fresh impetus in Germany.

The Puschmann bequest enabled Sudhoff to found an institute of the history of medicine, to build up a comprehensive medico-historical library and to visit the European libraries in order to study medical manuscripts, particularly medieval manuscripts. He was primarily interested in this aspect of medical history and published many hitherto unknown texts and documents. His institute was at this time the undisputed centre of research in medical history, and attracted scholars from all over the world. ${ }^{1}$ Many students wrote their dissertations under Sudhoff's guidance and edited medieval texts for him. He exerted his tremendous influence through his historical method, his writings and his dominating personality. The influence he exercised as teacher, was slight; he was a poor lecturer, and difficult to understand. Sudhoff was the great pioneer in medical history in Germany; he advanced the discipline through his researches, organized it, and gave it a definite place within the university. He founded the German society of history of medicine in 1901.

Sudhoff's Institute was the first research institute in the history of medicine. It served as an example and was soon to be followed by other universities. The Bavarian government created a chair in the history of medicine at the University of Würzburg in 1920. The medical school conferred it upon Georg Sticker, well known as a historian of epidemiology, especially plague, cholera, and venereal diseases. He built up a small institute; but after his retirement in 1934 the chair remained unoccupied and the rooms of the institute were used for other purposes. I do not know whether the government wanted to cut down the expenses of the university or the medical faculty had no interest in maintaining the chair.

The Prussian government founded a very well-endowed institute for the history of medicine and sciences at Berlin in 1929. Paul Diepgen was elected chairman. The institute comprised departments for medical history, history of the exact sciences, history of biology and for medicine and science in antiquity. It succeeded rapidly in achieving important research work and in attracting the attention of the learned world. Another institute was founded on the initiative of Karl Sudhoff at the University of Munich in 1935. Shortly before the war Walter Artelt, a pupil of Diepgen, was called from Berlin to Frankfurt and built up a beautiful institute there. I came from the Leipzig Institute to Bonn in 1942, where Carl Schmiz had lectured in the history of medicine since 1906. In 1943 I was given three rooms in the main building of the university for an institute, but it existed only until the end of 1944, when the entire building was destroyed in an air raid.

In 1925 Henry E. Sigerist succeeded Sudhoff in the chair at Leipzig. Sigerist had become increasingly interested in the sociological approach to history and developed the institute more and more along sociological lines. Sigerist's ideas are still alive today and are perhaps more effective than during his lifetime. He gave an enormous

${ }^{1}$ Cf. Henry E. Sigerist, 'University education', Bull. Hist. Med., 1940, 8, 3-21. 


\section{News, Notes and Queries}

impetus to the history of medicine. Being an excellent and dynamic teacher, he drew many people to the institute, and its rooms were often crowded with students and young doctors. The fact that he left for America in 1932 was an immense loss for German medical history.

After the war and after the fixation of the demarcation line between East and West there was practically no history of medicine in Western Germany. The small institutes of Munich, Frankfurt and Bonn had been destroyed, although fortunately their libraries had been saved. The University of Bonn was reopened in November 1945, and an institute of the history of medicine was rebuilt there. At this time the first postgraduate students came into the Bonn Institute, among them Gernot Rath, who became chairman of the Munich Institute. Some time later Walter Artelt reopened the Frankfurt Institute. Paul Diepgen went from Berlin to Mainz and took over a newly-established chair in medical history. His successor Edith Heischkel built up a very fine Institute in a temporary barracks building.

Our small group of medical historians endeavoured incessantly to convince the medical faculties that medical history is more than a delightful hobby for retired doctors, that a medical bibliophile is not yet a medical historian, that instruction in medical history would broaden the cultural horizon of the medical student and enable him to comprehend his work and the evolution of his profession. Fortunately we secured the assistance of the German board of physicians (Bundesärztekammer) and finally also of the association of German medical schools. In the beginning of the fifties the federal government was discussing the amendment of the medical curriculum (in West Germany the medical curriculum is settled and controlled by federal decree). We succeeded in convincing the competent authority of the need for a compulsory course in the history of medicine. The argument was as simple as it was evident: the physician should not be a mere skilled technician, but an educated and cultured man. He ought to be familiar with the achievements and the failures of his science and with the history of his profession and, from this knowledge, to derive the capability to judge critically what he is doing. The decree went forth in 1953 and obliged the medical schools which did not already have a chair to look around for trained medical historians.

Some medical schools had to resort to spare-time lecturers, in order to offer this course. There is no need to point out that this can become very dangerous: a boring lecture in the history of medicine is worse than no lecture at all. It therefore seemed necessary to support and promote institutes which were able to train postgraduates in the history of medicine, and to increase the number of these institutes.

In 1957 the federal government and the governments of the German states founded the Science Council (Wissenschaftsrat), with the task of preparing a general plan for the promotion of the sciences. In 1960 the Council published its first recommendations after long consultations with every discipline. The text of the recommendation for the history of medicine runs as follows:

'A chair for the history of medicine must exist in every medical school. But it will be very difficult to fill the chairs, because there is nearly no rising generation. The Science Council therefore suggests to promote first of all the institutes of Bonn, Frankfurt and Mainz, so that they can train new blood.' 


\section{News, Notes and Queries}

Our group was satisfied with this recommendation and expected that the medical schools would establish some new medico-historical institutes within the next ten years. But, to our utter astonishment, nearly every medical school without a chair in medical history started an institute within a few years. What had happened? It was the chief aim of the Science Council to change the traditional hierarchic structure of the German university and to modify the monocratic constitution of its institutions. Its recommendations therefore suggested the establishment of, for example, a second chair of physiology, pathology or surgery within the same medical school. These 'parallel chairs' were unusual at the time, and the medical faculties experienced considerable difficulty in establishing them, especially if the occupant of the first chair did not agree. On the other hand the state governments insisted on carrying out the recommendations of the Science Council. What was easier than satisfying their expectations and demands by founding a chair for the history of medicine? It seems to me that some medical faculties took the easy road. In consequence West Germany now has eighteen chairs in the history of medicine. All medical schools (except Saarbrücken and the newly-founded schools in Hannover, Bochum, Ulm and Aachen) now have medical history institutes.

The German institutes vary in the facilities they offer. ${ }^{1}$ They differ through the size and the holdings of the library, the number of fellowships for postgraduates (Assistentenstellen) and the fields of research, which obviously depend on the interests of the chairman. Smaller institutes have only one fellowship, while larger ones have two, three or four places for postgraduates. Some institutes have a photographic unit and their own photographer, some a special librarian. Since the leading feature of a scientific institute is research, I shall give some particulars about the main fields which are cultivated in our institutes of history of medicine.

The main field of research in the institutes of Hamburg and Giessen is Greek medicine; in Heidelberg, Arabic medicine; in Freiburg, medieval medicine; in Frankfurt, medicine of the seventeenth, eighteenth and nineteenth centuries; in Kiel, French medicine in the seventeenth and eighteenth centuries. Some institutes are mainly engaged in research into basic sciences or medical specialties: for example, Munich is cultivating the history of psychiatry, Münster the history of physiology, Mainz the history of pharmacology, Marburg the history of public health, Göttingen the history of scientific specialization, Düsseldorf the history of naval medicine and of allergy. Larger institutes with a greater staff are at work on several subjects; for example, Berlin on history of botany, Scandinavian medicine, history of dentistry, Akkadian, Arabic and medieval medicine.

The history of medicine is such a wide field that the few professional medical historians cannot adequately cover it. In Germany as in other countries the research activity of scholars from non-medical fields such as philologists, general historians, or medical practitioners and specialists, who devote their time to medico-historical subjects, is of considerable service to the discipline. It is indebted to them for many really important contributions and will never renounce their help.

Before discussing the teaching programme of our medical history institutes it is

1 Cf. James H. Cassedy, 'History of medicine and related sciences in Europe. Notes on teaching and study', Bull. Hist. Med., 1969, 43, 270-83. 


\section{News, Notes and Queries}

necessary to cast a glance at German medical education. During the minimum time of eleven semesters the medical student has to pass three examinations, the first in physics, chemistry and biology after two semesters; the second in anatomy, physiology and biochemistry after five half-years or three terms after the first examination; and the third relating to the theoretical and practical disciplines of the clinical stage after eleven semesters or six terms after the second examination.

When the student enters his name for the final examination, he must demonstrate that he has taken the required course in history of medicine during the clinical stage of his studies. In Bonn the course is offered for the seventh semester, that is the second semester of the clinical years. It comprises two hours every week or twenty-six to twenty-eight hours during the semester. According to the intentions of the legislators the course should cover the complete subject from antiquity to the twentieth century. But it is impossible to present the vast field in twenty-eight hours; only a superficial survey can be given in such a short time. The Bonn institute preferred therefore to explain and to illustrate a limited period in some depth and divided the course into four parts which are taught in four successive semesters: (i) Greek and Roman medicine; (ii) Arabic and western medieval medicine; (iii) Renaissance- and Baroquemedicine of the sixteenth, seventeenth and eighteenth centuries; and (iv) the development of scientific medicine in the nineteenth and twentieth centuries. It goes without saying that only one of these four-lecture courses is compulsory for the student. Some other German medical schools are following the same pattern. The German dental schools have also a required medical history course in their curriculum which the institutes of history of medicine are offering every second semester.

The teaching programme of the German medical history institutes includes a course for the first semester announced as an 'Introduction to medicine'. This course is compulsory in all Swiss universities; in Germany it is optional, but is attended by nearly all beginners. Its aim is to integrate the different fields and subsections of medicine within the student's mind and to give the beginner a first notion of the development and tradition of his profession and an idea of his future responsibilities to the individual and to the community. As a rule the course comprises two hours every week.

For senior students and staff members we offer every semester a research seminar on a special historic topic. In order to get the degree of 'doctor medicinae' (the German abbreviation is Dr.med.), the student has to submit a thesis. He can write it on any discipline of the medical school, even in the history of medicine. In the seminar he has the opportunity of reading a paper, from which a medical thesis may arise. For students preparing their theses we offer a course of introduction to medical bibliography. Nowadays it is unnecessary to emphasize how useful it is not only for students, but also for physicians and rising medical researchers.

Our teaching programme furthermore includes a reading course of two hours every week for students who do not want to forget the Latin they learned at school. There we read a Latin medical text and discuss it in relation to its time and to the part it played in the evolution of medicine, for instance a text of Celsus, Vesalius or Harvey or a treatise of the School of Salerno. Finally, scientific excursions are arranged to medico-historical museums and libraries, to famous medical schools, 
well-known hospitals, old spas, and other places of great medical achievements.

Society is always demanding that the medical schools produce better doctors. If they have the aim of giving the student an education which enables him to fulfil his duties and responsibilities as a member of the profession and of the community, a good medical historian may contribute remarkably to the realization of this project. Certainly, how to reach this goal is still a subject of lively discussion in Germany, as it is in other countries. ${ }^{1}$

JOHANNES STEUDEL

${ }^{1}$ Cf. Education in the History of Medicine, ed. by John B. Blake, New York, 1968.

\section{EPISTEME}

The critical review of history of medical and biological sciences Episteme grants to the Members of the various National Societies of the History of Medicine and of the History of Science a discount of 10 per cent on the subscription price for 1970 ( $\$ 8.00$ instead of $\$ 9.00$ ), on condition that the reduced subscription price of $\$ 8.00$ will be sent directly to the Administration of the review (Episteme, Via Orti 5, 20122 Milano, Italy) through bank check or international postal order, indicating at the same time the Society of which one is Member. The same discount is reserved also to the Libraries of the scientific and university Institutes. In 1970 Episteme will be issued in four quarterly numbers.

\section{UNIVERSITY OF PARIS, DEPARTMENT OF THE HISTORY OF MEDICINE AND SURGERY}

A series of lectures devoted to 'Medicine and Surgery in the Seventeenth and Eighteenth Centuries' is taking place in the Faculté de Médecine, Paris, from 8 January to 21 May 1970, under the chairmanship of the Professor of History of Medicine and Surgery, Prof. Charles Coury. The course includes historical lectures on the circulation of the blood, physiology, pathological anatomy, cardiology, infectious diseases, histology, obstetrics and gynaecology, hospitals, etc.; and the work of contemporary physicians and scientists will be discussed. 